\title{
The Relationship between Phonology and Inflectional Morphology in an Agrammatic Aphasic
}

\author{
Meryl Kobrin BA (Sp. \& H. Therapy) (Witwatersrand) \\ Lesley Wolk MA (Speech Pathology) (Witwatersrand) \\ Department of Speech Pathology and Audiology, \\ University of the Witwatersrand, Johannesburg
}

\begin{abstract}
The interaction between phonological and morphological breakdown in an agrammatic aphasic was investigated. Three linguistic tasks were constructed which were presented via two modes, reading and repetition. Results revealed that purely phonological consonant clusters were easier than clusters which contain a morphological component, and that these categories could be differentiated in terms of phonological error type. Inflectional omission was conditioned by phonological characteristics of the preceding segment. There was an interaction between the phonological and morphological hierarchies of difficulty in inflections which are homonyms phonologically. Findings suggest an interdependence between phonological and morphological breakdown in the agrammatic aphasic examined. Results were discussed with reference to clinical implications.
\end{abstract}

\section{OPSOMMING}

Die interaksie tussen fonologiese en morfologiese uitvalle in 'n agrammatiese afasia pasiënt is ondersoek. Drie linguistiese take is opgestel. Die pasiënt moes die take ouditief (deur middel van herhaling) en visueël (deur middel van lees) uitvoer. Resultate dui daarop dat suiwer fonologiese konsonant groepe makliker was om uit te voer, as groepe wat ' $n$ morfologiese komponent bevat het en dat hierdie kategorieë gedifferensieer kon word in terme van tipe fonologiese foute. Die voorafgaande segment se fonologiese karakteristieke het inflektiewe weglatings bepaal. Daar was interaksie tussen die fonologiese en morfologiese hiërargiese moeilikheidswaarde van infleksies wat fonologiese homonieme is. Bevindings dui op 'n interafhanklikheid tussen fonologiese en morfologiese uitvalle in die pasiënt. Resultate is bespreek met verwysing na kliniese implikasies.

To date, the trend within the psycholinguistic aphasia research has been to focus on the components of language (syntax, semantics and phonology) in isolation, rather than to investigate interrelationships between these levels of linguistic breakdown. The symptomatology of agrammatic aphasics, particularly their tendency to delete inflectional morphemes and their high proportion of phonemic errors, provides a unique opportunity to examine the mutual influence of phonologically and morphologically impaired systems.

lndependent research into phonologý and inflectional morphology has been well documented. Articulatory investigations have resulted in conflicting opinions as regards the nature of aphasic error performance. Johns and Darley (1970) and Shankweiler and Harris (1973), for example, support the notion that phonemic substitutions are primarily random, variable and unrelated to the target sound. Other investigators suggest that aphasic articulatory errors reflect systematic, rule-governed variations from the target phonemes (Blumstein, 1973; Marquardt, Reinhart and Peterson, 1979).

Studies exploring the performance of agrammatic aphasics on inflectional endings reflect a consistent hierarchy of difficulty for the various morphemes (Goodglass and Berko, 1960; Goodglass, 1976). De Villiers (1974) contends that explanations such as transformational complexity, semantic complexity, stress, redundancy and frequency of occurrence of each morpheme in normal adult speech are insufficient to explain the hierarchical morphemic impairment. This suggests that alternative explanations should be sought.

A number of theories have been proposed to account for the underlying deficits in agrammatism. Kean (1977) contends that agrammatism is an "... interaction between an impaired phonological capacity and otherwise intact linguistic capacities" (p. 10). This con- troversial phonological explanation has subsequently been criticized. Garman (1981) suggests that a number of Kean's arguments are based on misinterpretations of the existing literature. Kolk (1978) argues that although a phonological approach may have value with respect to the 'articulation' impairment in agrammatism, it does not provide a convincing argument to explain the syntactic omissions characteristic of these patients. Goodglass and Berko (1960) take an opposing view to Kean (1977) and suggest that grammatical function is more important than phonological structure in determining the difficulty of an inflectional ending. This theory is based on their finding that the plural, possessive and third person singular inflectional morphemes (all of which are homonyms phonologically) are omitted with differential frequency in agrammatic aphasics (Goodglass and Berko, 1960).

Martin, Wasserman, Gilden, Gerstman and West (1975) suggest that neither a purely phonological nor a purely morphological breakdown is sufficient to explain aphasic error performance. They propose that ".. it is the interaction of processes which is affected in aphasia rather than a specific impairment of a particular process or component"' (p. 449). This interactional model between phonological and morphological impairment has not been confirmed in the aphasia literature. However, several studies in child language have shown an interaction between syntax and phonology (Menyuk and Looney, 1972; Paul and Shriberg, 1982).

The paucity of research into the relationship between linguistic components in aphasia, provided a strong motivation for this study. The broad goal was thus to investigate the inter-relationship between phonological and morphological impairment in the expressive language of an agrammatic aphasic. The specific aims were: 1 . To compare the subject's error performance on consonant clusters which are purely phonological constructions (PC); clusters which 
are phonological constructions but with morphological possibilities (PCM); and clusters which are morphological combinations (MC). 2. To establish whether the subject's omission of inflectional morphemes is conditioned by the sonorance hierarchy of the preceding segment, as suggested by Kean (1977). 3. To examine the subject's production of three grammatical morphemes which are homonyms phonologically, namely the plural marker, the possessive marker and the third person singular, all of which are realized morphophonemically by the allophones $/ \mathrm{s}, \mathrm{z}, \mathrm{zz} /$.

\section{METHOD}

\section{SUBJECT}

The subject used in this study was R.P., a white, South African, English speaking female, aged thirty-eight years. In December 1978, she presented with a sudden onset of expressive aphasia. Computerized tomography revealed a left middle cerebral artery infarct, the etiology of which was unknown. No further neurological details were available. Pre-morbidly, she was right handed. R.P. fulfilled the following criteria:

1. She was a moderately impaired agrammatic aphasic as assessed on the Boston Diagnostic Aphasia Examination (BDAE) (Goodglass and Kaplan, 1972).

2. R.P. demonstrated phonemic errors, particularly on consonant clusters.

3. Her expressive language was characterized by omission of inflectional morphemes.

4. Dysarthria and oro-facial apraxia were excluded as being causally related to the phonemic errors.

5. Phonemic discrimination abilities were excluded as being etiologically related to phonemic errors.

6. R.P. demonstrated a competence for the tasks on which she would be expected to perform. More specifically, reading and auditory comprehension abilities, as assessed on the BDAE were sufficiently intact to enable these modalities to be utilized in testing.

7. R.P.'s mother tongue was English.

8. Peripheral hearing and vision were within normal limits.

9. R.P. was neurologically stable during the test period.

\section{TASKS AND PROCEDURE}

\section{A. Preliminary Investigations}

On the BDAE, R.P. obtained a profile representing Broca's (agrammatic) aphasia. Results served to satisfy some of the criteria for subject selection, specifically her relatively intact receptive language and reading abilities and the presence of phonemic and morphological errors.

On the Goldman Fristoe Test of Articulation (Goldman and Fristoe, 1969) R.P. showed several articulation errors on both single phonemes and phonemic sequences, verifying the presence of phonemic errors in meaningful words as elicited on a naming task.

On a test of Ten English Inflectional Morphemes, designed by the authors, R.P. demonstrated inflectional omission. In accordance with the format proposed by Goodglass and Berko (1960) a sentence completion test was constructed to assess the following morphenes: plural /s,z/; plural /az/; past /t,d/; past /ad/; present singular /s,z/; present singular /az/; possessive /s,z/; possessive /az/; comparative / $/ 2$; superlative /ast/. The test included six opportunities for the use of each morpheme selected. The following is an example of an item (plural) "I bought a large pot, a medium-sized pot and a small pot. Altogether I bought three -?".

On the Goldman Fristoe Test of Auditory Discrimination (Goldman, Fristoe and Woodcock, 1970), administered in order to verify the subject's competence for discriminating between single consonants, R.P. scored $100 \%$, indicating no errors on this standardized test of auditory discrimination.

R.P. responded adequately at all frequencies on a screening pure tone audiometric test, indicating that hearing was within normal limits.

\section{B. Tasks}

All tasks designed for the purpose of this study were evaluated by means of a pilot study on three normal adults.

\section{CCVCC word list}

A list of $150 \mathrm{CCVCC}$ words (Appendix l) was devised in accordance with the format proposed by Martin et al,. (1975). The stimuli were divided into three groups of fifty words each. In the first group, the final cluster was a purely phonological construction (PC) such as $/ \mathrm{mp} /$ in 'cramp'. In the second group, the final consonant cluster was a phonological construction, but the final segment belonged to the group $/ \mathrm{s}, \mathrm{z}, \mathrm{t}, \mathrm{d} /$ and therefore suggested the possibility of a morpheme (Martin et al., 1975). An example of a phonological construction with the morphological possibilities (PCM) is /st/ in 'breast'. The third group contained final consonant clusters which were morphological combinations (MC), such as /st/ in 'dressed'. The inflections included in the (MC) list in the present study were limited to the plural $/ \mathrm{s}, \mathrm{z} /$ and past $/ \mathrm{t}, \mathrm{d} /$, and in order to maintain uniformity, words in the PCM group were limited to the phonemes $(\mathrm{s}, \mathrm{z}, \mathrm{t}, \mathrm{d} /$ in final consonant position.

\section{Sonorance-Inflection word list}

A list of 150 words was composed (Appendix II). Each word was a combination of a stem morpheme ( $\mathrm{CV}$ or $\mathrm{CVC}$ ) and an inflectional morpheme (past /d/ or plural (z0), for example (bees, called). The stem morphemes were divided into five groups of thirty words each, according to the sonorance hierarchy of the final segment of the stem. Sonorance was used to refer to the extent to which the airflow is impeded during the articulation of a segment (Kean, 1977). The five categories of final stem segments arranged hierarchically from the most sonorant (least impeded airflow) to the least sonorant (most impeded airflow) were: vowels and diphthongs, liquids, nasals, fricatives and stops respectively. Within each group fifteen words were combined with the plural inflectional allophone $/ z /$ and fifteen words with the past inflectional allophone /d/.

\section{Rationale for selecting the allophones $/ z /$ and $/ \mathrm{d} /$}

Since stems ending in a vowel are constrained by morphophonemic rules to take a voice allophone, voiced allophones were used throughout. Several studies in the aphasic literature have shown that the plural is a relatively well retained morpheme whereas the past regular is a frequently omitted morpheme (Goodglass and Berko, 1960; de Villiers, 1974). These two morphemes were assessed in an attempt to control for the possibility of obtaining too few omissions (exclusive use of plural) or too many omissions (exclusive use of past), for between group com parison.

Martin et al., (1975) contend that the number of phonemes within a syllable is not significant in aphasic error performance on a given phoneme. Johns \& Darley (1970) suggest that the number of syllables is an important factor in error performance. For these reasons all stem and morpheme combinations were restricted to monosyllabic words of the structure CVC or CVCC. No initial clusters were included an an attempt was made to randomly vary the consonants utilized in initial position. 


\section{Phrase/Sentence list of plural, possessive and thind person singular}

In order to compare R.P.'s production of the plural marker, the possessive marker and the third person singular morpheme, a list of 135 sentences/phrases was compiled (Appendix III). The stimuli were divided into nine groups, so that each allophone $/ \mathrm{s}, \mathrm{z}, \partial \mathrm{z} /$ of each morpheme was tested fifteen times. Phrases were constructed since the possessive nature of a stimulus cannot be inferred from a single word. For example horse's in a repetition task would be interpreted as a plural. It was felt that a minimum of four syllables was necessary to convey the possessive nature of a stimulus, for example, 'the horse's mouth'. All stimuli therefore comprised four syllables.

\section{Administration of Tasks}

Each list was administered using two modes of presentation.

1. An auditory mode - repetition

2. A visual mode - reading

Two modes of presentation were selected because the stringent criteria adopted in test construction limited the number of stimuli available in certain groups. Due to the specific nature of the areas being investigated, a spontaneous sample, which may be considered as an ideal medium for linguistic investigation, would not have enabled sufficient sampling of all aspects under study.

For repetition tasks, R.P. was instructed to repeat each item after the experimenter. If no response was given the item was repeated. For reading tasks each item was printed clearly and individually in $10 \mathrm{~mm}$ capital letters. Word items were printed on $7 \mathrm{~cm}$ by $9 \mathrm{~cm}$ cards and phrase/sentence items on $14 \mathrm{~cm}$ by $9 \mathrm{~cm}$ cards. Each card was presented singly to R.P. and she was instructed to read it aloud. Testing was carried out on two different days for approximately forty-five minute periods in order to control for fatigue.

\section{Analysis Procedure and Scoring}

All responses were recorded on a Revox Tape Recorder (model 375 Dolby Version) and subsequently transcribed in broad phonetic script by three independent transcribers. A two out of three consensus was accepted for each word.

Analysis procedure specific to particular tasks

\section{CCVCC word list}

a) A frequency count of correct versus incorrect initial and final clusters in the three categories was carried out.

b) Phonological errors occurring in final clusters were differentiated according to type, on the basis of two broad categories, namely sequencing and substitution errors. Sequencing errors for the purposes of this study included additions, omissions and metatheses. In instances where a number of phonological errors occurred in one cluster, each was tabulated separately. For example, $/ \mathrm{st} / \rightarrow / \mathrm{tz} /$ was scored as both a sequencing and a substitution error.

\section{Sonorance-Inflection word list}

A frequency count of morphemes omitted, retained and incorrectly produced was carried out. The incorrect category included instances where R.P. retained a morpheme, but not the particular morpheme under stimulation; for 'example the allophone $/ z /$ instead of $/ d /$. Results were expressed as percentages.
3. Phrase/Sentence list of plural, possessive and third person singular

A frequency count of retained morphemes was carried out. A morpheme was considered as retained even if R.P.'s allophonic realization was not entirely accurate. For example, 'wishes' (third person singular) was realized by R.P. as $/ \mathrm{w}_{\mathrm{I}} \int \mathrm{J} /$ and this was scored as a retained inflection.

\section{RESULTS AND DISCUSSION}

Results of R.P.'s performance on each task will be presented individually and overall trends will be discussed in relation to the stated aims of this study.

\section{A comparison of R.P.'s error performance on PC, PCM and $M C$ consonant clusters}

a) Frequency count of correct versus incorrect consonant clusters

Table 1 Frequency count of correct versus incorrect initial and final consonant clusters

\begin{tabular}{|l|c|c|c|c|c|c|}
\hline \multirow{2}{*}{} & \multicolumn{2}{|c|}{ PC } & \multicolumn{2}{c|}{ PCM } & \multicolumn{2}{c|}{ MC } \\
\cline { 2 - 7 } & $\begin{array}{c}\text { Initial } \\
\text { Cluster }\end{array}$ & $\begin{array}{c}\text { Final } \\
\text { Cluster }\end{array}$ & $\begin{array}{c}\text { Initial } \\
\text { Cluster }\end{array}$ & $\begin{array}{c}\text { Final } \\
\text { Cluster }\end{array}$ & $\begin{array}{c}\text { Initial } \\
\text { Cluster }\end{array}$ & $\begin{array}{c}\text { Final } \\
\text { Cluster }\end{array}$ \\
\cline { 2 - 7 } & No. & No. & No. & No. & No. & No. \\
\hline Correct & 39 & 36 & 41 & 22 & 53 & 28 \\
\hline Incorrect & 61 & 64 & 59 & 78 & 47 & 72 \\
\hline Total $(\mathrm{N})$ & 100 & 100 & 100 & 100 & 100 & 100 \\
\hline
\end{tabular}

Table 2 Breakdown of correct initial and final clusters

\begin{tabular}{|l|c|c|}
\hline \multirow{2}{*}{ Category } & \multicolumn{2}{|c|}{ Correct Clusters } \\
\cline { 2 - 3 } & Initial Cluster & Final Cluster \\
\cline { 2 - 3 } & No. & No. \\
\hline PC & 39 & 36 \\
\hline PCM & 41 & 22 \\
\hline MC & 53 & 28 \\
\hline Total & 133 & 86 \\
\hline
\end{tabular}

Table 1 illustrates that R.P's incorrect final clusters increased in the progression $\mathrm{PC} \rightarrow \mathrm{MC} \rightarrow \mathrm{PCM}$. Table 2 provides a more specific breakdown of correct clusters. It indicates that within each category, more initial clusters were correctly produced than final clusters. For the purposes of this study, 'difficulty' was conceptualized as the number of incorrect clusters in a category. Martin et al. , (1975), in a similar study, conceptualized difficulty as the number of phonemic errors in a particular category. For example 'drink' / 'glink' contains two phonemic errors, whereas 'drink' / 'grink' contains one phonemic error. Martin et al. contend that the former production reflects greater difficulty than the latter. In this study, any two incorrect clusters were considered as being equally 'difficult', 
irrespective of the number of phonemic errors occurring in each. Results of the present study were not entirely consistent with Martin et al.'s, (1975) prediction of increased difficulty in the progression $\mathrm{PC} \rightarrow \mathrm{PCM} \rightarrow \mathrm{MC}$. However, the fact that incorrect final clusters increased in the direction PC $\rightarrow \mathrm{MC}$, supports the contention that due to the added cognitive decision component, a CCVCC word with two morphemes (e.g. dressed) would be more difficult for an aphasic to process than a CCVCC word which has one morpheme (e.g. trump) (Martin et al., 1975).

The fact that the PCM category reflected the highest frequency of incorrect clusters is difficult to explain. It is felt that the PCM category as proposed by Martin et al, (1975) needs careful consideration. Whether in fact the /st/ cluster in a word such as 'breast', for example, is interpreted as a possible morphological combination by the aphasic, is open to speculation. However, results of the present study, suggest that further research into whether the PCM category is conceptualized as a phonological or morphological construction, and whether such a category is in fact valid, could be of value in providing insight into the interaction between these two linguistic components.

The finding that initial clusters are more likely to be correctly produced than final clusters is consistent with that of Martin et al., (1975) who contend that the final cluster position may suggest the possibility of a morphological component which would thus pose a more difficult processing task to the aphasic.

b) Frequency count of sequencing versus substitution error types in final clusters

Table 3 Distribution of phonological errors in final cluster position according to sequencing and substitution error types

\begin{tabular}{|l|c|c|c|}
\hline \multirow{2}{*}{ Category of Error } & PC & PCM & MC \\
\cline { 2 - 4 } & No. & No. & No. \\
\hline Sequencing & 34 & 54 & 54 \\
\hline Substitution & 58 & 59 & 36 \\
\hline Total number of errors & 92 & 113 & 90 \\
\hline
\end{tabular}

Table 3 clearly illustrates that the three categories are distinguishable on the basis of error type. The PC category reflects a greater proportion of substitution versus sequencing errors; $M C$ a greater proportion of sequencing versus substitution errors; and PCM an approximately equal distribution of both.

The distribution of error types supports the contention that ". . . the substitution error is more indicative of a basic phonological impairment, while sequencing errors are more indicative of interactions between the phonological and morphological components" (Martin et al., 1975, p. 446). The approximately equal error distribution in the PCM category, seems to suggest the need for further research into the aphasics' conceptualization of this group as discussed above.

\section{Frequency count of omitted inflections as a function of the sonorance hierarchy of the preceding segment}

Table 4 represents a summary of morphemes retained, omitted and incorrectly produced, expressed in relation to $\mathrm{N}$. Omission of the morpheme increased in the order $\mathrm{V}$ (least omitted) $\rightarrow \mathrm{S} \rightarrow \mathrm{L} \rightarrow$ $\mathrm{N} \rightarrow \mathrm{F}$ (most omitted), where (V), (S), (L), (N) and (F), represent the sonorance category of the final segment of the stem. More inflections were retained following vowels than consonants. Within the consonantal group, the morpheme was most likely to be omitted when preceded by a fricative and least likely to be omitted when preceded by a stop. Kean (1977) hypothesized that omission of the morpheme would increase as the airflow in the articulation of a segment became more impeded, that is in the order $\mathrm{V}$ (least omitted) $\rightarrow \mathrm{L} \rightarrow \mathrm{N} \rightarrow \mathrm{F} \rightarrow \mathrm{S}$ (most omitted). This contention was not supported by the present results.

A possible explanation for the finding that the morpheme is more likely to be retained following a vowel than a consonant may be related to the syllable structure of words included in this task. Stem morphemes ending in vowels were of the construction CV (e.g. bee): while those ending in consonants were of the construction CVC (e.g. dog). Addition of the morpheme resulted in CVC stimuli for the vowel category (e.g. bees) and CVCC stimuli for the consonant category (e.g. dogs). Therefore retention of the inflection when the stem ends in a vowel, and omission when it ends in a consonant, may reflect a strategy to maintain the CVC syllable structure form. There is thus clear evidence to suggest that this subject has a tendency to employ simplification processes.

Shankweiler and Harris (1973) suggest that vowels are easier for aphasics to produce than consonants and that within the consonan-

Table 4 Distribution of morphemes retained, omitted or incorrectly produced, expressed as a function of the sonorance hierarchy of the stem final segment

\begin{tabular}{|c|c|c|c|c|c|c|}
\hline & & \multicolumn{5}{|c|}{ Sonorance hierarchy of final segment of stem morpheme } \\
\hline & & $\begin{array}{c}(\mathrm{V}) \\
\text { Vowel Diphthong } \\
\mathrm{N}=49^{\mathrm{a}}\end{array}$ & $\begin{array}{c}(\mathrm{L}) \\
\text { Liquids } \\
\mathrm{N}=12^{\circ}\end{array}$ & $\begin{array}{c}(\mathrm{N}) \\
\text { Nasals } \\
\mathrm{N}=52^{\mathrm{a}}\end{array}$ & $\begin{array}{l}\quad(\mathrm{F}) \\
\text { Fricatives } \\
\mathrm{N}=34^{\mathrm{a}}\end{array}$ & $\begin{array}{c}(\mathrm{S}) \\
\text { Stops } \\
\mathrm{N}=46^{\mathrm{a}}\end{array}$ \\
\hline Retained & $\%$ & 81,63 & 33,40 & 36,50 & 32,30 & 45,60 \\
\hline Omitted & $\%$ & 16,37 & 41,60 & 50,00 & 64,70 & 32,60 \\
\hline Incorrect & $\%$ & 2,00 & 25,00 & 13,50 & 3,00 & 21,80 \\
\hline Total & $\%$ & 100,00 & 100,00 & 100,00 & 100,00 & 100,00 \\
\hline
\end{tabular}

aN $=$ The number of words in which the final segment produced by R.P. corresponded to the category under investigation. 
tal group, fricatives and affricates are more susceptible to error than other phonemes. The present findings suggest that the omission of inflections may be conditioned by the susceptibility to error or "complexity of articulation' of the preceding segment.

It appears that although R.P's inflectional omission was not conditioned strictly by the sonorance hierarchy of the preceding segment, omission and retention were influenced by certain phonological characteristics of this segment as well as the overall syllable structure of the word. If her inflectional deletions were solely attributable to a syntactic impairment, an equal percentage of omissions would have been expected across all groups. Verification of the present trends on a large group of agrammatic aphasics, assessing a variety of inflectional morphemes, may provide strong evidence for an interaction between phonological and morphological breakdown.

\section{Frequency count of retained plural, possessive and third person singular morphemes as a function of their stimu- lus allophonic realization}

Table 5 Distribution of retained plural, possessive and third person singular morphemes as a function of their stimulus allophonic realization

\begin{tabular}{|c|c|c|c|c|}
\hline $\begin{array}{c}\text { Stimulus } \\
\text { Allophonic } \\
\text { Realization }\end{array}$ & $\begin{array}{c}\text { Plural } \\
\text { No. }\end{array}$ & $\begin{array}{c}\text { Possessive } \\
\text { No. }\end{array}$ & $\begin{array}{c}\text { Third Person } \\
\text { Singular } \\
\text { No. }\end{array}$ & $\begin{array}{c}\text { Total } \\
\text { No. }\end{array}$ \\
\hline$/$ s/ & 24 & 13 & 14 & 51 \\
\hline$/ z /$ & 24 & 7 & 8 & 39 \\
\hline$/ 2 z /$ & 30 & 17 & 28 & 75 \\
\hline Total & 78 & 37 & 50 & 165 \\
\hline
\end{tabular}

Table 5 clearly illustrates that the frequency of morpheme retention increases in the progression: possessive (least retained) $\rightarrow$ third perśon singular $\rightarrow$ plural (most retained). The frequency of allophonic retention increases in the progression $/ \mathrm{z} /$ (least retained) $\rightarrow / \mathrm{s} / \rightarrow / \mathrm{zz} /$ (most retained). This pattern is maintained for each individual inflection, with the exception of plurals where $/ \mathrm{s} /=/ \mathrm{z} /$.

An interactional analysis reveals that:

- Third person singular /az/is better retained than plurals /s/ and $/ \mathrm{z} /$.

- Possessive /az/ is better retained than third person singular $/ \mathrm{s} /$ and $/ z /$.

- Possessive /s/ is better retained than third person singular $/ \mathrm{z} /$.

\section{Morphological Complexity}

The hierarchy of grammatical difficulty exhibited by R.P. is consistent with reports in the literature (de Villiers, 1974; Goodglass, 1976).

\section{Phonological Complexity}

For the purposes of the present study, any realization of the allophone was tabulated as a retention of the stimulus allophone. This phonological scoring procedure precluded strict comparison with other writers, who considered the allophone as either correct or in- correct. However, the fact that R.P. retained the syllabic allophone $/ \mathrm{az} /$ with greater frequency than the non-syllabic form $/ \mathrm{s}, \mathrm{z} /$ is consistent with the findings of Goodglass (1976) and in opposition to those of De Villiers (1974). Goodglass (1976, p. 250) ascribes the greater retention of the syllabic form /az/ to the added 'saliency' of the extra syllable. He states that "there is no basis at present for anything but a first order intuitive definition of saliency as the resultant of information, load, affective tone, increased amplitude and intonational stress" (Goodglass, 1976, p. 253). It is clear that this definition of saliency, includes both réceptive and expressive components. Therefore, if saliency, as delineated above by Goodglass (1976), were the sole explanation for the present findings, greater retention of the voiced $/ \mathrm{z} /$ as opposed to the unvoiced $/ \mathrm{s} /$ would have been expected, particularly on repetition tasks. However, the fact that R.P. showed greater retention of $/ \mathrm{s} /$ as opposed to $/ \mathrm{z} /$, suggests that alternative explanations, possibly with phonological implications should be sought. Wolk (1978) reported that woiced fricatives may be more susceptible to error in aphasics than their voiceless cognates, which may explain R.P.'s greater retention of the stimulus allophone $/ \mathrm{s} /$ as opposed to $/ \mathrm{z} /$.

Whilst some explanations have been provided, a more complete account of the above findings would involve detailed consideration of receptive language and perceptual factors, which is felt to go beyond the scope of this study. However, R.P.'s differential retention of the stimulus allophones $/ \mathrm{s} /$ and $/ \mathrm{z} /$, suggests that further research into receptive language and phonemic perception in agrammatic aphasics, may provide valuable information.

\section{Interactional Analysis}

The finding that syllabic forms of more complex morphemes are more likely to be retained than non-syllabic forms of less complex morphemes, provides strong evidence for an interaction between apparent phonological and morphological hierarchies of difficulty.

\section{MAJOR TRENDS}

Overall, the following trends exhibited by R.P. in this study, suggest an interdependence between the phonological and morphological levels of breakdown for this case:

la. Consonant clusters of purely phonological construction were more likely to be correctly produced than clusters containing a morphological component or suggesting the possibility thereof.

b. The cluster categories PC, PCM and MC were clearly differentiated in terms of the proportion of sequencing versus substitution errors. PC reflected a greater proportion of substitution errors, $\mathrm{MC}$ a greater proportion of sequencing errors and PCM an approximately equal distribution of both.

2. Inflectional deletion appeared to be conditioned by phonological characteristics of the preceding segment as well as the syllabic structure of the word.

3. There was an apparent interaction between the grammatical and phonological hierarchies of difficulty in three morphemes which are homonyms phonologically.

\section{CONCLUSIONS}

Results of this study reflect a mutual interdependence between the phonologically and morphologically impaired systems of this agrammatic aphasic patient. Such findings contradict the notions that agrammatism is a uniquely phonological deficit (Kean, 1977) or that it is a disruption of the syntactic component of language co-occurring with an independent disorder of articulation (Berndt and Caramazza, 1981, p. 171). An interactional model between phonology and morphology, suggesting a unitary linguistic representation is strongly 
indicated Verification of the present trends on a large group of agrammatic aphasics may support the contention that therc is no single impairment at a specific level in agrammatism. Rather, a complex interaction of linguistic processes, all of which arc opcrating at a reduced level of efficiency would bc indicated (Martin et al., 1975). Such a model highlights the inherent limitations of fragmenting the linguistic components in the treatment of agrammatism and suggests a number of clinical implications for the aphasiologist. Firstly, diagnostic procedures could possibly include a description of morphological breakdown in the context of phonological breakdown, rather than two detailed but separate analyses. Secondly, phonological environments conditioning the omission of inflectional morphemes should be evaluated for each patient and thcrapy could proceed from phonologically simpler to more complex contexts.

Further rescarch into the relationship between linguistic components in both aphasia and child language disorders is indicated. This would not only facilitate a morc holistic approach to the management of these patients, but would providc greater insight into the organization of language components in a linguistically intact system.

\section{REFERENCES}

Berndt, R.S., \& Caramazza, A. Syntactic Aspccts of Aphasia. In Acquired Aphasia, M.T. Sarno (Ed.) New York, Academic Press, 1981.

Blumstein, S.E. Somc Phonological Implications of Aphasic Speech. In Psycholinguistics and Aphasia, H. Goodglass \& S.E. Blumstein (Eds.) Baltimore, Johns Hopkins University Press, 1973.

De Villiers, J. Quantitative Aspects of Agrammatism in Aphasia. Cortex, 10, 36-54, 1974.

Garman, M. Is Broca's Aphasia a Phonological Deficit? In Linguistic Controversies, D. Crystal (Ed.) London, Edward Arnold, 1981.

Goldman, R., \& Fristoe, M.S. Goldman-Fristoe Test of Articulation, Minnesota, American Guidance Service, Inc., 1969.
Goldman, R., Fristoe, M.S., \& Woodcock, R.W. Goldman-Fristoe Test of Auditory Discrimination. Minncsota, American Guidance Service, Inc., 1970.

Goodglass, H. Agrammatism. In Studies in Neurolinguistics, H. Whitaker \& H.A. Whitaker (Eds.) Vol. 1, New York: Academic Press, 1976.

Goodglass, H., \& Berko, J. Agrammatism and Inflectional Morphology in English. J. Speech Hear. Res., 3, 257-267, 1960.

Goodglass, H., \& Kaplan, E. The Assessment of Aphasia and Related Disorders. Boston Vcterans Administration Hospital and Aphasia Research Centre, Department of Neurology, Boston University, 1972.

Johns, D.F., \& Darley, F.L. Phonemic Variability in Apraxia of Specch. J. Speech Hear. Res., 13, 556-583, 1970.

Kean, M.L. The Linguistic Interpretation of Aphasic Syndromes: Agrammatism in Broca's Aphasia: An Example. Cognition, 5, 9-46, 1977.

Kolk, H.H.J. The Linguistic Interpretation of Broca's Aphasia. A reply to M.L. Kean. Cognition, 6, 349-362, 1978

Marquardt, T.P., Reinhart, J.B., \& Petcrson, H.A. Markedness Analysis of Phoncmic Substitution Errors in Apraxia of Speech. J. Commun. Dis., 12, 481-494, 1979.

Martin, A.D., Wasscrman, N.H., Gilden, L., Gerstman, L., \& West, J.A. A Process Model of Repetition in Aphasia: An Investigation of Phonological and Morphological Intcractions in Aphasic Error Performance. Brain and Language, 2, 434-450, 1975.

Menyuk, O., Looney, P.L. Relationships Among Components of the Grammar in Language Disorders. J. Speech Hear. Res., 15, 395-406, 1972.

Paul, R., \& Shriberg, L. Associations Between Phonology and Syntax in Speech-Delaycd Children. J. Speech Hear. Res., 25 , 536-553, 1982.

Shankweiler, D., \& Harris, K.S. An Expcrimental Approach to the Problem of Articulation in Aphasia. In Psycholinguistics and Aphasia, H. Goodglass and S.E. Blumstein (Eds.) Baltimore: Johns Hopkins University Press, 1973.

Wolk, L. A Markedness Analysis of Initial Consonant Clusters in Aphasic Phonological Impairment: A Case Study. S. A.J. Commun. Disord., 25, 81-100, 1978.

\section{APPENDIX I}

CCVCC WORD LIST

PURELY PHONOLOGICAL CONSTRUCTION (PC)

$\begin{array}{llllll}\text { blank } & \text { frank } & \text { clasp } & \text { cramp } & \text { drench } & \text { shrink } \\ \text { blanch } & \text { brink } & \text { clench } & \text { crank } & \text { drink } & \text { French } \\ \text { blink } & \text { brisk } & \text { clinch } & \text { crunch } & \text { drunk } & \text { fring } \\ \text { branch } & \text { clamp } & \text { blimp } & \text { brunch } & \text { flank } & \text { frisk } \\ \text { breadth } & \text { clank } & \text { clump } & \text { crisp } & \text { flask } & \text { frum }\end{array}$

$\begin{array}{llll}\text { grange } & \text { stump } & \text { trump } & \text { spunk } \\ \text { grasp } & \text { stink } & \text { clamp } & \text { spank } \\ \text { plank } & \text { stamp } & \text { tramp } & \text { stench } \\ \text { scalp } & \text { plump } & \text { shrimp } & \text { trench } \\ \text { slump } & \text { prank } & \text { trunk } & \text { stomp }\end{array}$

PHONOLOGICAL CONSTRUCTION WITH MORPHOLOGICAL POSSIBILITY (PCM)

$\begin{array}{llllll}\text { blind } & \text { breast } & \text { cleft } & \text { crux } & \text { friend } & \text { glance } \\ \text { blitz } & \text { bronze } & \text { craft } & \text { draft } & \text { front } & \text { glint } \\ \text { blond } & \text { bland } & \text { crest } & \text { drift } & \text { frost } & \text { craft } \\ \text { blunt } & \text { brunt } & \text { grant } & \text { flex } & \text { grunt } & \text { grand } \\ \text { brand } & \text { cleanse } & \text { crust } & \text { flux } & \text { gland } & \text { grind }\end{array}$

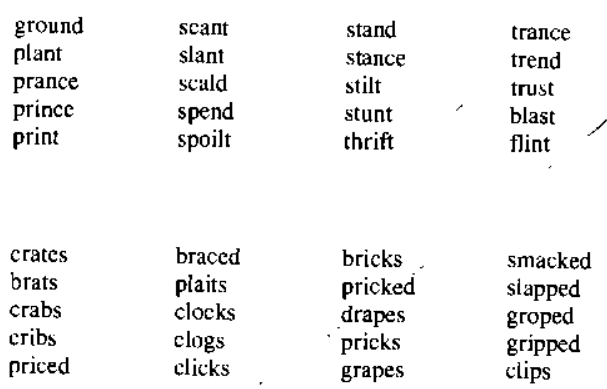

PHONOLOGICAL CONSTRUCTION WITH MORPHOLOGICAL COMBINATION (MC)

$\begin{array}{llllll}\text { frogs } & \text { tricks } & \text { spots } & \text { flossed } & \text { stabbed } & \text { dressed } \\ \text { planes } & \text { plans } & \text { slides } & \text { planned } & \text { flipped } & \text { crossed } \\ \text { spoons } & \text { llags } & \text { sticks } & \text { groaned } & \text { gripped } & \text { pressed } \\ \text { steps } & \text { stoves } & \text { closed } & \text { flocks } & \text { bragged } & \text { placed } \\ \text { frills } & \text { spades } & \text { stocks } & \text { grabbed } & \text { blessed } & \text { plates }\end{array}$


APPENDIX II

SONORANCE - INFLECTION WORD LIST

\begin{tabular}{|c|c|c|c|}
\hline \multicolumn{2}{|c|}{ VOWELS AND DIPTHONGS } & \multicolumn{2}{|c|}{ LIQUIDS } \\
\hline$|z|$ & $/ \mathrm{d} /$ & $\mid \mathrm{z} /$ & \\
\hline bees & lied & bills & bowled \\
\hline fees & wcighed & bulls & rolled \\
\hline knees & cared & bells & called \\
\hline keys & died & wills & pulled \\
\hline peas & sighed & walls & wailed \\
\hline bears & tied & wells & sailed \\
\hline pears & paid & pools & piled \\
\hline firs & toyed & pills & filed \\
\hline ways & feared & pals & ruled \\
\hline boys & reared & shells & fooled \\
\hline toys & wired & sales & cooled \\
\hline goes & hired & goals & peeled \\
\hline cows & shared & girls & sealed \\
\hline fears & dared & mills & mailed \\
\hline shears & sheared & tills & railed \\
\hline
\end{tabular}

$\begin{array}{ll}\text { NASALS } & \\ \text { /z/ } & \text { /d } / \\ \text { farms } & \text { bombed } \\ \text { palms } & \text { combed } \\ \text { psalms } & \text { dimmed } \\ \text { charms } & \text { roamed } \\ \text { rams } & \text { nanied } \\ \text { lambs } & \text { tamed } \\ \text { worms } & \text { timed } \\ \text { bins } & \text { shunned } \\ \text { buns } & \text { pinned } \\ \text { fins } & \text { sinned } \\ \text { pans } & \text { dined } \\ \text { sons } & \text { moaned } \\ \text { sins } & \text { fined } \\ \text { vincs } & \text { signed } \\ \text { signs } & \text { shamed }\end{array}$

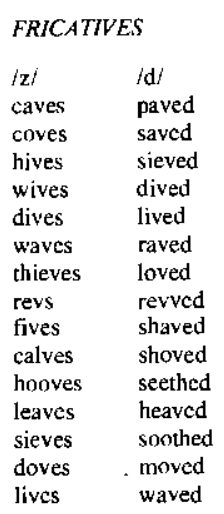

STOPS

\section{APPENDIX III}

PHRASE/SENTENCE LIST OF PLURAL, POSSESSIVE AND THIRD PERSON SINGULAR

\section{PLURAL /s/}

I have big cats

Give me red mats

Take the pips out

Turn the lights off

I will buy pots

I wear white socks

I like my shirts

They are white rats

I like pet shops

He took big sips

We both hate bats

We have red gates

I have two kites

I buy eight books

Give me the sacks

POSSESSIVE /S/

The cat's big paw

Pat's little boy

Kate's big red hat

The hat's ribbon

The pet shop's door

The cup's handle

The white rat's tail

The pet's delight

The cake's icing

The lake's water

The'rake's handle

The book's cover

Rick's baby girl

The pope's red robe

The pot's handle

THIRD PERSON SINGULAR /s/

The young boy laughs

The big dog barks

The big boy fights

That young man jokes

The good boy writes

He likes to run

He wants to cat

She puts it in

He takes it out

She sips the coke

He eats the cake

He pats the dog

The young man talks

The goud boy waits

The white dog bites
PLURAL /z/

I have big dogs

She has two bags

I bought the pigs

$\mathrm{He}$ ate two figs

I hurt both legs

$\mathrm{He}$ made the beds

I found the logs

I like the jugs

I have two jobs

I bought two wigs

He took two rods

Pass me the rags

Here are two rugs

I saw lion cubs

I bought two nibs

POSSESSIVE /a/

The dog's collar

The jug's handle

Bob's little girl

Dad's new red car

The boy's handle

The big pig's hoof

The bird's one wing

The bed's one leg

The pub's doorway

The lad's new toy

The lab's doorway

The mob's loud noise

Rob's new baby

The bud's petal

The rug's colour

\section{THIRD PERSON SINGULAR /z/}

Hc begs for food

She rubs her leg

He rides the bike

He robs the bank

Pat jogs to work

He wags his tail

She hugs the boy

He lugs the chair

She digs a hole

She leads the way

He reads the book

She fecds the dog

Tim guides the man

He bides his time

He fibs often
PLURAL /AZ/

Two big horses

They arc nurses

Two red purses

Take two buses

I like sauces

Run the races

Take two paces

Tie your laces

Two sad faces

Two big cases

Take two wishes

Two big bushes

Wash the dishes

Two long sashes

Two hard courses

POSSESSIVE /OZ/

The nurse's hat

The Jones's car

The horse's mouth

James's big hat

Liz's red shoe

The fish's mouth

The witch's nose

The boss's car

The case's kcy

Gus's new car

Roz's new hat

Roz's new hat

's door

Dez's new cat

Bess's red hat

Madge's new cas

THIRD PERSON SINGUIAAR /az'

He washes it

He rushes home

He dashes home

$\mathrm{He}$ wishes once

She cashes it

$\mathrm{Hc}$ misses her

She kisses him

It gushes out

She bashes him

He watches her

It mashes food

$\mathrm{He}$ fishes there

She pushes him

He lashes out

She dishes up 
THIS PAGE IS SPONSORED BY

\section{LITERARY SERVICES (PTY) LTD} ACADEMIC \& MEDICAL BOOKSELLERS

\author{
JOHANNESBURG: CAMPUS BOOKSHOP \\ 34 Bertha Street \\ 2017 Braamfontein \\ WESTDENE SERVICES \\ 76 King George Street \\ 2001 Hillbrow
}

PRETORIA:

DURBAN:

LOGANS WESTDENE 660 Umbilo Road 1400 Durban

WESTDENE - MEDIO 36 Nedbank Plaza 175 Beatrix Street Arcadia Pretoria

CAPE TOWN:
WESTDENE RONDEBOSCH 18 Main Road 7700 Rondebosch

\section{PHONE:}

(011) 339-1711

PHONE:

(011) 339-1711
PHONE:

(012) 266366

(012) 3233487

\section{PHONE:}

(031) 253221 Ext 22 